https://doi.org/10.18485/iipe_ru_sr.2020.ch13

\title{
MILITARY AND POLITICAL SECURITY PROBLEMS. COMMON THREATS AND CHALLENGES IN THE OSCE REGION
}

\begin{abstract}
Andrey Y. Malov ${ }^{1}$
Abstract: The article asserts that the persistent alarming trend towards a further increase of the conflict potential in relations between the West and Russia is reflected on the security situation in Europe.

The Alliance has been pursuing a course towards the militarization of Europe for the fifth year, running under the pretext of countering the contrived Russian threat. This course is accompanied by exerting massive informational pressure on Russia.

The COVID-19 pandemic triggered purely selfish approaches to ensuring security and added to the general instability.

The idea of a Wider Europe without dividing lines and bloc confrontation actually turned out to be unrealized. It will be difficult to expect any breakthroughs in relations and the creation of foundations to ensure European security as long as the course for the aggressive military containment of Russia continues.

A substantive and productive dialogue is required to overcome mutual fears and increase the level of trust. The re-establishment of professional contacts, including those at the military level, is needed in order to avoid misunderstanding of each other's intentions and prevent the descent into an uncontrolled escalation of tensions.

Keywords: strategic stability, arms race, arms control, antiballistic missile defense, escalation of tensions, security architecture, transparency and confidence-building measures, structured dialogue.
\end{abstract}

${ }^{1}$ Ph.D., Associate Professor, Department of International and National Security, Diplomatic Academy of the MFA of Russia.

E-mail: aymalov5353@mail.ru 


\section{Background analysis}

The security situation on the European continent is developing unfavorably. The tension is growing. Moreover, new lines of contradictions and exacerbations appear.

We all know that European security was largely identical to global security for many years. The stability and predictability of the entire system of international relations built on the basis of the UN Charter and the basic principles of international law depended on the state of affairs in Europe.

Nowadays, one of the European security problems is connected with the fact that Europe and the Euro-Atlantic area are generally losing their key system-forming role. New centers of power and influence are emerging, the Asia-Pacific region - is a convincing example. The habitual old center of power is compelled to carry out an ever-intensifying competition for a place in the sun and for the privilege to shape the international security landscape based on its preferences, and the world order based on its own patterns. ${ }^{2}$

COVID - 19 has also said its piece. The pandemic not only affected the health of Europeans but also exposed serious systemic gaps in the health care system and painfully hit the entire social sphere.

Politically and strategically, the pandemic was a serious sustainability test and a test of the effectiveness of the mutual support system within the framework of such multilateral structures as the EU and NATO and not only them. It triggered purely selfish approaches to ensuring security and worked rather for disconnection than for interaction.

All this could not but affect the state of security affairs on the European continent, including in the military and political dimensions. ${ }^{3}$

\footnotetext{
${ }^{2}$ Huntington S.P. The Clash of Civilizations and the Remaking of the World Order. - New York, N.Y.: Simon and Shuster, 1996. - 367 Р.; Подберёзкин А.И. Значение Локальных Человеческих Цивилизаций (ЛЧЦ) как субъектов формирования международной обстановки (М0) в мире // ЦВПИ. 13 февраля 2020 [Electronic resource]. - URL: www.eurasian-defence.ru

[Podberyozkin A.I. Znachenie LCHC kak subjektov formirovaniya MO v mire // CVPI. 13 fevralya 2020. - URL: www/.eurasian-defence.ru]

${ }^{3}$ Клаузевиц К. фон. О войне. Избранное. М.: АСТ. 2019. - 318 с.

[Klauzevic K. fon. 0 vojne. Izbrannoe. M.: AST. 2019. - 318 s.]
} 
Currently, we continue to face a persistent alarming trend towards a further increase of the conflict potential in relations between the West and Russia. Under pressure from Washington, which is pursuing its geopolitical course despite the growing contradictions within the American elites, NATO countries are increasingly getting involved in an aggressive antiRussian stand.

At the same time, following a certain pause associated with the abovementioned COVID crisis, the western elites continue to pursue a course of unilateral economic sanctions, trade and financial wars, extraterritorial application of national legislation, blackmail and even, threats to use force. This course is accompanied by exerting massive informational pressure on Russia and attaching propaganda labels "revisionist" and "aggressor" to it new know-hows at the information age. ${ }^{4}$

In our opinion, an extremely destructive process of ideologizing the geopolitical confrontation is underway. It is complemented by dehumanizing the opponent - in this case, Russia - and imparting the immanently inherent properties to it, supposedly not organically coinciding with the basic European values. ${ }^{5}$ Moreover, after the active phase of the pandemic, this process does not fade, but only begins to intensify.

It seems that these actions reflect the ongoing attempts of the Western elites to impose their understanding of the world order and establish a monopoly on the implementation of globalization not as a balanced and inclusive process, but as a project in the interests of the elites. In practice, this only leads to a sharp exacerbation of contradictions, to new faults and lines of confrontation. ${ }^{6}$

The matter is not limited only to measures of political, economic, and psychological pressure. NATO is currently focused on countering the contrived Russian threat. With this pretext, the Alliance has been pursuing a course towards the militarization of Europe for the fifth year running.

\footnotetext{
${ }^{4}$ Castells M. The rise of the network society: The information age: economy, society, and culture. - John Wiley \& Sons, 2011. - T.1.

${ }^{5}$ Tomes R. Releaning Countersurgency Warfare / US Army War College, 2004.; Overextending and Unbalancing Russia. RAND. 2019.

${ }^{6}$ Nye J.S. The future of power. - Public Affairs, 2011. - 320 P.; Modern Political Warfare. Current Practices and Possible Responses. RAND. Cal., 2018. - P.8
} 
Military contingents appear where they have never been before on a continuous rotational basis. NATO is focusing on fighting "the threat from the East". Along the Russian borders, military infrastructure is being deployed and modernized and large-scale exercises are being conducted.

Thus, over 50 thousand soldiers practiced offensive and defensive actions in low temperatures during the Trident Juncture exercises in 2019. Logistic and infrastructural capabilities of the European countries are being rebuilt in order to transfer significant forces and resources to the Russian borders, including the transfer of American military contingents from overseas. From the expert point of view, this is a very remarkable sign of real military preparations. Thus the focus is being made on military predominance. $^{7}$

The scale and intensity of the exercises increased and their provocative focus strengthened. The Bloc's geopolitical expansion continues in the Balkans. The once militarily stable regions of Northern Europe, the Baltic states and the Black Sea, have been turned into "frontline zones" in the short term. The development of the US ABM systems and NATO ABM systems continues. ${ }^{8}$

It will be difficult to expect any breakthroughs in relations and the creation of foundations to ensure European security as long as the course for the aggressive military containment of Russia continues. Besides, a real material basis for military and strategic capabilities is being created, the

\footnotetext{
${ }^{7}$ The National Defense Strategy of the United States of America, 2018. [Electronic resource]. The Department of Defense official website. - URL: https: // www.defense.gov/Portals/1/Documents/pubs/2018-National-Defense-StrategySummery.pdf

${ }^{8}$ NATO missile defense. FAS Special Report 1. September, 2011. [Electronic resource]. - URL: https:// fas.org/pubs/_docs/2011\%20Missile\% 20 Defense\%20 Report.pdf. Frank A.Rose. Growing global Cooperation on Ballistic Missile Defense. Remarks as prepared for delivery in Berlin, Germany. September 10, 2012. [Electronic resource]. The U.S. Department of State website. - URL: http: // www. state.gov/t/avc/rlss/ 197547.htm

Frank A Rose. Implementation of the European Phased Adaptive Approach. Remarks at Polish National Defense University Warsaw, Poland. April 18, 2013. [Electronic resource]. The U.S. Department of State website. - URL: http: // www. state.gov/t/avc/ rls/2013/207679.htm
} 
infrastructure of which has come very close to the Russian borders. Measures to modernize the US tactical nuclear potential on the continent and to give it the characteristics of a "battlefield weapon" are becoming a reality; the practice of the "joint use" of nuclear weapons (nuclear sharing) also continues, which is a direct violation of the NPT.

All this is complemented by an unprecedented increase in NATO military budgets up to $\$ 1$ trillion. ${ }^{9}$

Speaking about the alleged non-orientation of NATO against Russia, one should note the sharply increased activity of the Alliance on the "eastern flank". As specific examples, it is appropriate to cite the activities of the Alliance in the Baltic and Black Sea regions, and the Arctic zone. The intensity and scale of military exercises, involving carriers of nuclear weapons, including strategic ones, are increasing. The total number of the armed forces of the Alliance countries is currently more than 3 million people. Military measures are accompanied by instruments of "hybrid" influence - pressure in the economic sphere, anti-Russian propaganda and expulsion of diplomats. Thus, the basis for long-term psychological and power pressure on Russia is being created. ${ }^{10}$

The crisis potential is also growing in other parts of the world. The results of NATO military operations in Europe (Yugoslavia) and beyond its borders (Afghanistan, Libya) include numerous civilian casualties, destruction of infrastructure, significant economic damage, actual disintegration of states, and violation of the fundamental principles of international law. Apparently, the Alliance is solving the problem of "projecting stability" outside its area of responsibility in this way.

\footnotetext{
${ }^{9}$ National Defense Authorization Act for Fiscal Year 2019 / Congress. [Electronic resource]. - URL: http://www.congress.gov>115/crpt/hrpt676/CRPT-115hrtp676.pdf

${ }^{10}$ Overextending and Unbalancing Russia. RAND. 2019. Modern Political Warfare. Current Practices and Possible Responses. - Cal., RAND. 2018. -P.8

Попов И.М., Хамзатов М.М. Война будущего. Концептуальные основы и практические выводы. Очерки стратегической мысли. 3-е изд., испр.М.: Кучково поле, 2019. - 832 с.

[Popov I.M., Hamzatov M.M. Vojna budushego. Konceptual nye osnovy I prakticheskie vyvody. Ocherki strategicheskoj mysli. 3-e izd., ispr. M.: Kuchkovo pole. 2019. - 832 s.]
} 
This course is strengthened by ongoing "humanitarian and peacekeeping operations", which affirms the Alliance's move beyond its geographical responsibility. That hardly contributes to the harmonization of international relations. ${ }^{11}$

Visible military preparations are accompanied by practical steps in the new areas of confrontation, such as space. ${ }^{12}$

All this demonstrates how far the Western elites are ready to go in order to maintain a monopoly on global strategic decisions and on shaping the political, financial, economic, and value-based world landscape.

Despite the emerging centrifugal tendencies in NATO and statements about the "death of the organization's brain", the Alliance is actively looking for a new mission in new conditions.

At the same time, Washington continues its consistent course to increase the individual defense spending of allies, keeping in mind the sale of its military products. ${ }^{13}$

Simultaneously, the institutions of interaction were thrown into crisis, the Russia-NATO Council was frozen, and the arms control architecture is being consistently undermined. One gets the impression that NATO is looking for meanings of its existence. Now, when the Alliance celebrated the 70th anniversary of the organization's founding not so long ago, it becomes more obvious that we are dealing with a vestige of the Cold War, which NATO is trying to reanimate and to which it is trying to give new "expanded" functions.

In this context, NATO's strategic course to replace international law with "NATO legitimacy", "rules of international behavior" and the imposition of the globalizing Alliance's role based on these rules could be evaluated as a long-term challenge. ${ }^{14}$

${ }^{11}$ Operations and Missions past and present. - URL: https: //www.nato.inthepsh natohqtopics_52060

${ }^{12}$ Trump reauthorizes U.S. Space Command / Spaceflight Now // - URL: http://www.Spaceflightnow.com

${ }^{13}$ Remarks by President Trump at Signing Ceremony for s.1790, National Defense Authorization Act for Fiscal Year 2020 // The White House, December 20, 1919.

${ }^{14}$ The globalizing role of NATO has been confirmed by the Active Engagement. Modern Defense strategic concept adopted in November 2010. [Electronic resource].

- URL: // https: //www. nato.int/cps/ru/natohq/official_texts_68580.htm 
Thus, the idea of a Wider Europe without dividing lines and bloc confrontation actually turned out to be unrealized. The commitments enshrined at the highest level in the fundamental documents of the OSCE and the Russia-NATO Council not to strengthen their security at the expense of the security of others were ignored. ${ }^{15}$

On the contrary, in reality, we are dealing with the gradual expansion of NATO, and the deployment of global anti-missile defense elements in the interests of the US on a continent located a thousand miles away from them. Talks about the fact that this structure is not directed at Russia arouse doubts among professionals, to put it mildly. ${ }^{16}$

The fact that the Europeans actually allowed themselves to be drawn into the process of deliberately increasing the level of confrontation with Russia, accompanied by significant costs from the imposed sanctionsrelated activities, has become a reality. ${ }^{17}$

The consequence of such a short-sighted policy is the agreement system erosion in the field of arms control and limitation. A clear example is the INF Treaty that ceased to exist in August 2019, the disruption of which the US stubbornly pursued. The course of events shows that the Americans had been preparing a decision to withdraw from the INF Treaty for a long time - they needed only a pretext. The termination of the Treaty is a blow to strategic stability and European security architecture. It is acknowledged by most European politicians. Attempts to shift the responsibility onto Russia look like manipulation of European public opinion and justification of Washington's own preparations in this area.

Speaking about the INF Treaty, another fact is surprising - how easily Washington managed to convince the Europeans to give up their security on the basis of such a lightweight and unconvincing pattern.

15 Данилевский Н.Я. Россия и Европа. М.: Академический Проект, 2015. - 602с. [Danilevskij N.YA. Rossiya I Evropa. M.: Akademicheskij Proekt, 2015. - 602 s.]

${ }^{16}$ Frank A Rose. Implementation of the European Phased Adaptive Approach. Remarks at Polish National Defense University Warsaw, Poland. April 18, 2013. [Electronic resource]. The U.S. Department of State website - Mode of access http: // www. state.gov/t/avc/rls/2013/207679.htm

${ }^{17}$ Measuring Geopolitical Risk Caldara, Dario and Matteo lacoviello [Electronic resource]. - URL: https //dol.org/10.17016/IDDP.2018.1222 
At the same time, efforts continue to shift responsibility for the collapse of the INF Treaty onto Russia. This case is as senseless as it is unsightly. It is obvious that this is the choice of the American side, which has rejected the practical measures proposed to it for transparency and trust, as well as for removing the accumulated concerns regarding the Treaty.

Essential measures should include Russia's commitment not to deploy the INF in Europe and other regions until American missiles appear there. Unfortunately, neither Washington nor its NATO allies have responded to this commitment in a concrete manner - the sweeping accusations continue.

As for another cornerstone of security - the situation with the extension of the 2010 START Treaty remains uncertain. The timid signals accompanying the Russian-American discussion of strategic stability issues in Vienna could only give hope for progress in this area.

Thus, we face a situation of growing uncertainty in international relations, in which the strategic stability system is increasingly showing a high degree of deterioration. ${ }^{18}$

It seems that Russia and the need to contain it both in the military and political sense and in the value-based dimension will remain the main factors justifying the very existence of the Alliance in modern conditions. In this context, it should be expected that these principles will be reflected in the forthcoming new strategic concept of NATO. The core of NATO's anticipated future strategic concept will likely be its orientation against Russia. ${ }^{19}$

The Western countries' consolidation in the face of an imaginary common threat from Russia is only one of the factors providing new meanings of the Alliance. Ideological considerations are among other unifying goals: an alliance of "democracies" against "authoritarian regimes" that refuse to accept rules to establish a new world order. In addition, one should take into account the highly pragmatic geopolitical intentions of

${ }^{18}$ Koblentz G.D. Strategic Stability in the Second Nuclear Age / Council on Foreign Relations. Special Report № 71. November 2014

${ }^{19}$ Штоль В.В. Россия и Запад: несостоявшийся альянс, или Противостояние как неизбежность. СПб. : Алетейя. 2019. - 434 с.

[SHtol V.V. Rossiya i Zapad nesostoyavshijsya alyans, ili Protivostoyanie kak neizbezhnost'. SPb.: Aletejya.2019. - 434 s.] 
NATO and the pursuit to secure by force the right to access energy resources. All this is evident in the increased activity in the Arctic region.

It is very appropriate in this regard to quote the words of NATO Secretary-General Anders Fogh Rasmussen, which he said on September 16,2014 , that "only NATO is the provider of that political legitimacy and military power that no country or coalition can provide". ${ }^{20}$

These claims indicate the Alliance's course towards a "monopoly" of legitimacy, which, among other things, is a challenge to the central role of the UN and its Security Council in resolving international problems.

The fact that NATO countries have the powerful collective military capacity - i.e., possibilities, confrontational rhetoric - i.e., intentions and concrete actions - i.e., practical deeds towards Russia does not allow to trust statements about the defensive nature of the Alliance.

\section{New areas of confrontation are also emerging}

Analysis of the key doctrinal and policy documents of the US, and recently NATO, on this topic, shows that the leadership of the country and the Alliance is increasingly considering space as a zone of growing vital interests, as well as a factor and condition for ensuring national security and military predominance in possible armed conflicts.

As for the US policy documents, the Pentagon issued a directive on space policy in October 2012.

The document declares that any interference with the activities of American space systems, including ground infrastructure, is considered a "violation of the rights" of the US and will require "reciprocal actions." The document is also indicative because it essentially lays down the parameters for the creation of a "space NATO", within the framework of which an attack in space or an attack on "space" objects of one of the Alliance member states on Earth will be considered as an attack on all of them. ${ }^{21}$

${ }^{20}$ Speech by NATO Secretary-General Anders Fogh Rasmussen at Carnegie Europe. A force for Freedom. September 16. 2014. [Electronic resource]. - URL: https: // www.nato.int/cps/en/natohq/opinions_113063.htm? selectedLocale=en

${ }^{21}$ Directive of the United States Department of Defense on Space Policy №3100.10, October 18, 2012 Space Directive [Electronic source] // Defense Technical 
Currently, we are witnessing the active phase of this project's implementation. The Alliance's space policy was preliminarily approved at the meeting of NATO defense ministers in June 2019. ${ }^{22}$

NATO allies are practically joining the space military race. Attention was drawn to the speech of the French Defence Minister Florence Parly, who presented the national military space doctrine in July 2019. This is the first document of this nature, and it will undoubtedly affect the situation in space.

The doctrine also implies the adoption of a special program called "space management". France's space defense strategy aims to build capacity to conduct military operations in space using space-based means by 2030 .

Taking this into account, one cannot but come to a logical conclusion that the plans of France and NATO, in general, have the ultimate goal of deploying strike weapons in space. And this despite the fact that Russia and France are actively interacting in "peaceful" space in the field of creating delivery vehicles and operating satellite systems, as well as developing space science. ${ }^{23}$

At the same time, the very search for diplomatic measures is essentially rejected. Forceful actions become the dominant factor in resolving such issues. Russian initiatives to prevent space from becoming a battlefield are in fact ignored by the US and its NATO allies.

The substantive negotiating work of the Conference on Disarmament (CD) in Geneva has been suspended for more than twenty years. Against this

Information Centre [official website]. - URL: http://www.dtic.mil/whs/directives/ corres/pdf/310010p. pdf); 2011 National Security Space Strategy (NSSS) [Electronic source] // Defense Technical Information Centre [official website]. - URL:http:// www.dtic.mil/dtic/tr/fulltext/u2/a536546.pdf

${ }^{22}$ НАТО утвердила концепцию альянса по сдерживанию в космосе / TACС. [Electronic resource]. - URL: https://tass.ru/mezhdunarodnaya-panorama/6600988 NATO utverdila konzepziju alijansa po sderzhivaniju v kosmose/TASS. -

[Electronic resource]. URL: https://tass.ru/mezhdunarodnaya-panorama/6600988

${ }^{23}$ Как Франция собирается милитаризировать свою космическую доктрину / Le Monde. [Electronic resource]. - URL: https://inosmi.ru/politic/20190726/2455 29943.html

Kak Franzija sobiraetcja militarizirivat`svoju kosmicheskuju doctrinu Le Monde. - URL: https://inosmi.ru/politic/20190726/245529943.html 
backdrop, Russia's proposal to adopt a mandate for launching negotiations concerning a Treaty on the Prevention of the Placement of Weapons in Outer Space, the Threat or Use of Force against Outer Space Objects (PPWT), which provides for a ban on the placement of weapons of any kind in outer space and on any use of force against space objects, the initial draft of which was submitted jointly with China within the CD back in 2008, and the amended version - in 2014, remains unfulfilled. ${ }^{24}$

We do hope that the joint efforts of the planned Working Group on space strategies and concepts of Russian and French experts could result in better mutual understanding in this strategic sphere.

\section{Peacekeeping as a tool of influence}

Special attention should be given to the forceful expansion of NATO's influence using a tool for peacekeeping. NATO has developed its own model of peacekeeping. Since 2008, NATO has begun to conduct its own peacekeeping operations without much regard for the UN, going beyond its zone of responsibility, which in fact can be qualified as geopolitical expansion under the pretext of peacekeeping using the mechanism of civilmilitary cooperation as a tool for "democratic" changes. ${ }^{25}$

One has the right to ask oneself a question whether the policy goal of the Alliance, limited in its membership to 30 member countries, is to replace the UN. In any case, in peacekeeping, for example, we are already witnessing such a trend. Attempts to replace international law with "NATO legitimacy" are one of the reasons for the current European security crisis.

\section{What is happening in the Alliance itself?}

As for the Alliance itself, including the Washington-Euro-NATO course, it becomes clearer that NATO remains an unexpectedly demanded mechanism

${ }^{24}$ See Draft - Treaty on the Prevention of the Placement of Weapons in Outer Space, the Threat or Use of Force against Outer Space Objects [Electronic source] // United [Official website]. - URL: http://www.un. org/ru/document/ods.asp?m=CD/1985

${ }^{25}$ Phillips W.R. Civil-Military Cooperation: Vital to Peace implementation in Bosnia // NATO Review. 1998. Vol.48. №1. P.22-25 
if we consider the situation from the angle of attempts to discipline the allies and consolidate American dominance over them on a new level and in new conditions. This is especially important in the context of COVID19 - the factor which has "worked" for disconnecting rather than unifying.

Paradoxically, this course is accompanied by fierce financial and economic competition between the US and Europe. Europe is increasingly questioning whether to sacrifice its competitiveness for American military backup. This trend is supported by centrifugal tendencies associated with both the "Trump factor" and the US readiness for "situation coalitions" with non-Alliance members and, in general, with the declining readiness of the "old Europeans" to sacrifice their economic and financial competitiveness for the sake of American security guarantees.

This was particularly evident in relations between Washington and Berlin, especially around the issue of the construction of the Nord Stream2 gas pipeline.

It seems that the "COVID crisis" only contributed to further exacerbation of these contradictions. In these conditions, in addition to the Baltic states, Poland, which is positioned to play a role of the main "cementing" link of the Alliance in its opposition to Russia, is increasingly advancing to the number of countries expressing a high interest in NATO guarantees, primarily from the US.

It also seems that Brussels and Washington do not see the future of the Alliance in the same way. Simultaneously, Europe realizes that it is compelled to increase its contribution to European security, as NATO understands it. A greater contribution, however, does not at all mean a fair distribution of responsibility, whereby Europe could actually rather than declaratively be an equal partner for the US.

It appears that the "capitalization" of the US assets in NATO under the present turmoil conditions in the US themselves may have a backfire effect on the Alliance itself, whose fundamental value is being tested by the policy of individual state interests.

Despite the emerging centrifugal tendencies in NATO and statements about the "death of the organization's brain", the Alliance is actively looking for new meanings, a new mission in new conditions, and creating a working group to develop a new strategy. At the same time, Washington continues 
its consistent course to increase the individual defense spending of allies, keeping in mind the sale of its own military products.

Meanwhile, the EU, being a strong economic player, manifests itself fairly passively when it comes to the issues of international security and strategic stability. In fact, the EU reacts weakly to Washington's deliberate undermining of the system of international treaties in the field of arms control and allows itself to be drawn into the sweeping demonization of Russia and in the course to intensify the confrontational line towards Moscow.

It is quite indicative that, despite the numerous conversations about the creation of a "European army", the prospects for the activities of such a structure as PESCO are still hard to see. ${ }^{26}$

Nevertheless, no doubt that NATO will be able to "digest" the tendency towards "Euroseparatism" and will remain to exist as an Alliance. The potential problem, though, could come from a predicted even greater level of geopolitical aggressiveness of the Alliance - the "differentiated product" intended to become a condition for the survival of this structure.

\section{Missed opportunities}

Thus, we should note the chance, missed in the 90 s, to build a truly democratic system of European security based on equality and taking into account the interests of all states on the continent. Instead, the Alliance, which virtually lost the reason for its existence with the end of the Cold War, has embarked on a course of expansion. As a result, the dividing lines in Europe that existed in the Cold War bloc confrontation era were not erased but only moved further to the East.

It is becoming increasingly clear that one of the goals of the Alliance's expansion was the desire to isolate Russia and create a "cordon sanitaire"

\footnotetext{
${ }^{26}$ Журкин В.В. Европейская армия: Поражения и победы. Общая политика безопасности Европейского Союза. М.: Международные отношения, 2012. Jurkin V.V. Evropejskaja armija: Porazhenija I Pobedi. Obshsaja politika bezopasnisti Evropejskogo Sojuza. M.: Mejdunarodnije ontnoshenija, 2012.
} 
around it. But, it is also more clear that it is impossible to address the common security issues without working jointly with Russia.

Meanwhile, a really alarming situation has now emerged, in contrast to the repeated periods of "cold spells" and "thaws" in relations with NATO periods after the events in Yugoslavia in 1999 and after the armed venture of Saakashvili's regime in South Ossetia in 2008, on the one hand, and after the signing of the Pratica di Mare Declaration on a new quality of cooperation in 2002 and after the NRC Lisbon summit, on the other.

This time the European countries are in fact participating in an aggressive anti-Russian policy, accompanied by a sharp increase in military presence near the borders of Russia and allied Belarus. That could only lead to the risks of unintentional incidents and an escalation of military and political tensions.

The crisis in Ukraine, which was triggered by the unconstitutional coup in 2014 and, more recently, around the elections in Belarus, as well as the fictitious "Russian threats" associated with them, are used today as an excuse for the militarization of Europe pursued at the expense of European taxpayers.

It is also fundamentally important to realize that the course to undermine the international legal order was taken by the West long before the Ukrainian crisis.

Long before the abovementioned events, NATO did not support any of the Russian initiatives to form a united and indivisible security space in Europe. The most tangible blow to strategic stability was delivered long before the Ukrainian and Georgian events - back in 2002 when the US unilaterally withdrew from the ABM Treaty.

The missed opportunity to sign the Charter for a New Europe back in 1990 is deliberately silenced. For many years, Russia was led to believe that the accession of Central and Eastern Europe countries to NATO would improve relations with Moscow and create a belt of states friendly to Russia. In fact, all this turned out to be a myth.

On the contrary, the core of the security policy of the Alliance states is now the thesis about the need for their special protection from Russia. The West apparently forgot that it was Russia that made a decisive contribution to the elimination of the Cold War material legacy. After all, it was Russia that carried out the demilitarization of Eastern Europe by withdrawing 
troops out of there and making a specific contribution to strengthening European security.

Moreover, NATO expansion at the last stage occurs not due to the free choice of states, but due to their forceful involvement in the Alliance. This was the case with Montenegro, where they did not take into account the overwhelming opinion of its population, and North Macedonia, where the national referendum results were ignored. Thus, the main criterion for admitting new members is not their allegedly comprehensive compliance with NATO standards and requirements, but, above all, considerations of political expediency and geopolitical and strategic long-term calculations.

The threat of the escalation of tension hangs over Europe itself. The rise of aggressive radical nationalism and neo-Nazism and uncontrolled migration are overlaid with the lingering Cold War legacy.

Thus, contrary to the goals declared in the OSCE documents, the European security space remains fragmented.

At the same time, the bloc countries turned out to be not fully ready to cooperate equally with Russia in the areas of common interests and to build a genuinely inclusive European security architecture without dividing lines.

NATO is deliberately avoiding continuing constructive dialogue and systematic work on military issues. There are only occasional meetings and contacts, which does not provide an opportunity for de-escalation and defuse and for reducing military and political tensions in Europe.

It is obvious that the absence of civil and military cooperation with Russia (programs to combat terrorism and WMD proliferation do not in fact work) is a purely politically motivated decision. The only channel remained is the dialogue between military leaders, which really could be of help in the present circumstances aimed at reducing the risk of a military confrontation, but which is vividly not enough.

In general, it should be noted that it turned out to be more painful for the Western elites than expected to realize and admit that after a period of catastrophic disintegration processes in the territory of the USSR, nowadays the world has a serious player in the face of Russia.

And this player happens to have its own opinions and interests, which, if ignored, could only lead to instability and lack of balance. The legitimate 
nature of the strategic interests of Russia is acknowledged by competent western experts. ${ }^{27}$

It seems reasonable to continue strengthening the Western elites' awareness of this reality through political and diplomatic dialogue and expert meetings.

\section{General suggestions}

Given the limited potential of Russian influence on the state of affairs in NATO itself and the absence, in contrast to the 70s and 80s of the 20th century, of a significant anti-war protest political movement in Europe, it is important to develop a bilateral dialogue with Alliance individual participants. ${ }^{28}$

The focus should be on the heavy demand for regular contacts between military experts in order to reduce the military threat and prevent unpredictable incidents.

Despite the presence of objective difficulties, the European space, often called the OSCE space, can still be a platform for an equal and non-politicized dialogue on the most pressing security issues.

De-escalation of military tensions, countering transnational threats, and conflict resolution are called upon to become the central areas of such a dialogue.

Taking into account the existing difficulties, it is appropriate to focus on the remaining structures of pan-European interaction, in particular, on the Vienna Document 2011 - without attempts to unreasonably modernize it and on the Open Skies Treaty (OST), which, in our opinion, has not lost the main elements of its viability, despite the blow struck in the form of Washington's decision to withdraw from the Treaty.

As for the "structured dialogue" on security challenges, launched at the OSCE Ministerial Council in Hamburg in 2016, it has not brought the expected result yet. The Russia-NATO Council could have its say here. The

\footnotetext{
${ }^{27}$ Clinton Rich. Strategic Report // RAND, Cal., 2017.

${ }^{28}$ Public support for peace building. September 2017/ Sociology June -July 2017. [Electronic resource]. - URL: www.revalgeldesigns.co.uk
} 
focus of attention could be a substantive expert dialogue on the military and political aspects of security with the involvement of the military. Possible topics include a discussion of ways to prevent incidents and dangerous military activities, as well as to reduce military activity along the RussiaNATO line of contact, and practical de-escalation measures.

Such a pragmatic approach could lead to the recovery of the dialogue and its activation and contribute to finding ways to restore confidence and reduce the confrontation level in Europe. However, such a dialogue is possible only based on equality and mutual consideration of interests.

At the same time, it is important not to politicize it and not to turn it into an additional mechanism of unilateral pressure on Russia and unfounded accusations against it. ${ }^{29}$

It is difficult to say now whether such a dialogue will be able to turn into negotiations on a wide range of political and military issues, not to mention the real aspects of arms control.

In Europe, there are enough important and demanded topics directly related to the aspects of tight security. Among them are terrorism, organized crime, drugs, cybercrimes, and so on. All this needs a joint coordinated response. ${ }^{30}$

We do not have to search for ready-made interaction structures. These are, on the one hand, the specialized structures of the OSCE. On the other hand, the CSTO, whose member countries have considerable experience in responding to such threats, have repeatedly expressed their readiness for interaction.

The CSTO partnership institute tends to build its capacity, including through the involvement of Chinese colleagues and the SCO's capabilities, in particular, open integration projects.

${ }^{29}$ Daniel R Coats Director of National Intelligence/ Worldwid Threat Assessment of the US Intelligence Community. Febr. 13, 2018. - P. 15. [Electronic resource]. - URL: https//www.aremed-services.senate.gov/imo/media/doc/Coats_03-06-18.pdf;

Russian Military Power. - Defense Intelligence Agency, 2017. P.1-VII, +86.

${ }^{30}$ Th.Freat, L.Kulesa, D.Raynova. Russia and NATO: How to overcome deterrence instability? / Euro-ATLANTIC Security Report/EuropeanLeadership Network, 2018. April. -P.2 
It seems that the idea of a Greater Eurasian space is quite applicable to the security sphere and not only to joint economic and humanitarian projects. It is also quite compatible with the idea of building a continentwide architecture of equal and indivisible security. It is important, at the same time, to rely on the decisions of the OSCE summit in Astana in 2010 on the establishment in Europe, in the OSCE area, of a free, democratic, common and indivisible community, which can be created if there is the proper political will.

For Russia, and ultimately for Europe as a whole, long-term security projects can be effective. In this context, it is worthwhile, in our opinion, to think about returning to the idea of a European Security Treaty, the Russian draft of which has been practically rejected upfront by Western partners in its own time.

\section{Specific areas of interaction}

The course towards the "forceful" containment of Russia objectively works to slow down the 2011 OSCE Vienna Document on confidence and security measures. What kind of in-depth practical measures of transparency and trust, that is, measures to update the VD 2011, can we talk about in the atmosphere of deliberately increased confrontation, which, apparently, is considered as one of the instruments of the "policy to coerce" towards Russia? Not to mention the policy of sanctions and the lack of military cooperation. ${ }^{31}$

It seems that, under the current conditions, we can only talk about the fulfillment of existing obligations under the VD.

Meanwhile, this direction objectively has a significant potential to improve the military and political situation, which is difficult to realize without clarifying the fate of the Conventional Arms Control Regime in Europe (CACE). After all, we all understand that the CFE Treaty mechanism has long become a relic, and its adapted version did not find real support from NATO countries and never entered into force.

${ }^{31}$ Gompert D., Binnendijk H. Power to Coerce // RAND Cal.,, 2016. P.5-10 
As for the fate of the CACE regime, the development of new approaches to it is possible on the condition that the principles of equal and indivisible security, as well as a balance of rights and obligations, be observed.

At the same time, a joint discussion with the OSCE partners is highly desirable in order to find starting points for a possible transition to a practical conversation on the CACE new image. In this context, the question arose about finding an adequate platform to build a dialogue on such a basis. It seems that, given the objective prevailing circumstances, it will be very difficult to use the formal settings at the present. One would think about the possibilities provided by the "second" track, or better yet, by a "one-and-ahalf" track. The very possibility to launch such a dialogue within the OSCE could be viewed as a positive dynamic.

\section{The "structured dialogue" launched by the decision of the OSCE Ministerial Council in Hamburg (2016) deserves special consideration}

This process made it possible to successfully start a frank and focused discussion of truly pressing issues: the perception of challenges and threats in the OSCE area, military doctrines, trends in the guise of armed forces and military exercises as well as and the risks arising from these trends, challenges to the rule of law in the field of European security and prospects for military contacts and cooperation.

Despite deep disagreements over the reasons for the current situation and the threat assessments, the dialogue participants have repeatedly spoken out in favor of overcoming negative trends and reducing the confrontation level, including by developing measures to prevent incidents, exercising mutual restraint and transparency, re-establishing military contacts, improving the implementation of existing agreements and developing new agreements on arms control as well as by building confidence and security.

In addition, despite the parties' disagreements over the figures and facts characterizing the current military and political situation, the benefits of a joint analysis of relevant trends in order to create a generally accepted factual basis for further discussions were recognized. 
However, it has proven difficult to develop commonly understood and recognized methodological aspects of such an analysis. The disagreements in approaches to ensuring security were too deep. First of all, these are fundamental differences in approaches to the goals, objectives, and coverage of the dialogue.

So, when adopting the relevant declaration of the Ministerial Council in Hamburg in 2016, many Europeans proceeded from the assumption that a change in the US leadership would allow to fairly quickly start rebuilding relations with Russia and, consequently, improving the situation (including military and political) in Europe. Accordingly, they also hoped to move away from general discussion to discuss specific agreements, in particular, on arms control, within a year.

When it became clear that it is here to stay, the "structured dialogue", however, began to increasingly bog down in attempts to politicize the discussions and return them from consideration of specific military and political issues to fruitless debates about "violations of the fundamental OSCE principles". Nevertheless, it should be admitted that the Americans have repeatedly stated during the discussions that they basically do not object to the Russian thesis that the "structured dialogue" at the current stage should be first aimed at de-escalating tensions.

However, not all representatives of Western countries agree with this thesis. Some of them continue, out of a long-standing habit, to talk about the intrinsic value of "transparency" and about the Vienna Document's modernization. Others are not at all ready to limit the "structured dialogue" to talking only about the military aspects of security.

At the same time, the "old Europeans" would like to revive the conversation specifically on arms control and confidence-building measures and to look into options for de-escalating military and political tensions in the OSCE area.

Thus, there is no unity on a number of fundamental issues under the dialogue, even among Western countries.

It seems that progress in this direction is possible only with the active involvement of military experts and, what is most important, with the political will of all the participating states, which is not clearly visible yet.

The Chief of the General Staff of the Russian Federation, General of the Army, V.V. Gerasimov has been deliberately focusing on the importance of 
the elaboration of specific measures aimed at de-escalating military tensions along the contiguity line of NATO and the RF. Concrete suggestions were transmitted to the NATO leadership in 2019.32

It is certainly encouraging that most of the dialogue participants do not want to lose a potential channel of informal communication, primarily between the military, and the atmosphere at the site of the "structured dialogue" is calmer than at the weekly meetings of the OSCE Permanent Council and the FSC.

Thus, we have a right to draw a general conclusion: the Germans' plans to gradually narrow the "corridor" of discussions in that area to military and political security aspects (consistent with the well-known Steinmeier's initiative) have not worked yet.

However, it is highly revealing that nobody hastens to "bury" the initiative, also because no other "strategic" project has been developed to replace it.

Thus, the guidelines for the "structured dialogue" generally remain rather blurred, especially considering the attempts of a number of countries to channel the discussions towards criticism of Russia and attacks on it for "undermining the European order". The future of this dialogue remains to be questionable.

\section{Forum for Security Cooperation (FSC)}

Speaking of the FSC, it should be emphasized that the situation in Ukraine and the ongoing crisis in Russia-West relations had a determining influence on its activities. Fundamental differences in approaches to the

\footnotetext{
32 The Chief of the General Staff of the Russian Federation, General of the Army V.V. Gerasimov has been deliberately focusing on the importance of the elaboration of specific measures aimed at de-escalating military tensions along the contiguity line of NATO and RF. Concrete suggestions were transmitted to the NATO leadership in 2019. Seе: Герасимов В.В. Роль и место контроля над вооружениями в системе обеспечения безопасности Российской Федерации. Московская Конференция по Европейской Безопасности // Под ред. А.И. Антонова 23-24 мая 2013 г. [Gerasimov V.V. Rol' I mesto kontrolja nad vooruzhenijami v sisteme obespechenija bezopasnosti RF / pod redakzii A.I. Antonova 23-24 maja 2013].

Russian Military Power. - Defense Intelligence Agency, 2017. P.1-VII, +86.
} 
military and political situation assessment and the advancement prospects in key areas of the forum's activities were acutely revealed during the preparation and conduct of the OSCE Ministerial Council. It is getting harder to coordinate the final documents, even on seemingly "neutral" issues.

In this context, the results of Russia's chairmanship of the FSC (AprilAugust 2017) look very illustrative. It appears that the course taken on focusing attention on topics uniting all OSCE participating States has paid off. As it is known, the best practices accumulated by Russia were submitted (preventing incidents on and above the high seas, countering the diversion of small arms and light weapons into illegal circulation, disposing ammunition, and creating an effective export control system). The speeches of the representatives of regional organizations involved in ensuring security - the speeches of the SCO Secretary-General (for the first time in the OSCE history) and the CSTO Deputy Secretary-General - aroused considerable interest.

Participants indicated that this, to a certain extent, contributed to the improvement of the atmosphere at the FSC and the intensification of the OSCE's cooperation with Russia and indicated organizations. Russia's chairmanship was well appreciated by other participating states.

It seems that the strict adherence to the VD - 2011 and other agreements, the de-escalation of the situation and the restoration of military contacts should remain among the important topics in the FSC activities and the "structured dialogue".

\section{Open Skies Treaty (OST)}

The situation around the OST is developing very ambiguously.

Most of the open skies missions were conducted in a spirit of mutual understanding and cooperation. The Open Skies Consultative Commission (OSCC) was engaged (in early 2017 - under Russia's chairmanship) to ensure the strict implementation of treaty provisions. The Small Format Group (Russia, the US, Canada, Germany, Poland, Italy, Sweden) searched for a mutually acceptable "package" solution to the problems of the Treaty implementation. 
However, in line with the general escalation of tensions in relations with Russia, the US began to tighten its approaches, accusing Russia of violating the Treaty, primarily in connection with the introduction of the maximum flying range over the Kaliningrad region $(500 \mathrm{~km})$. The work in the "small format" was virtually curtailed by the US. In the fall of 2017, Washington took unilateral steps, which were announced to be aimed at returning Russia within the Treaty framework. These actions (canceling sleepovers at two airfields, changing the maximum flying range, redistributing open skies airfields, and refueling airfields and their functions) were frankly aimed at creating maximum inconvenience for Russian open skies missions conducted over the US.

In response, the Russian side was obliged to cancel sleepovers at three Russian airfields when carrying out flights with the participation of the US, as well as to terminate a number of bilateral technical agreements and unilateral measures that were used as a demonstration of good faith and previously facilitated the conduct of American missions over Russia.

It became clear that the spiral of measures and countermeasures would continue to unwind, with relevant consequences for the Treaty. Further developments confirmed these fears. An extremely destabilizing blow to the OST was delivered by the US withdrawal from the Treaty.

At the same time, there are indications (including the plans of a number of states to develop open skies aircraft and digital observation equipment) that many OST participants, primarily Western Europeans, would not want to lose the Treaty. Thus, two opposite trends in the development of the situation around the OST have emerged to date - confrontational and constructive.

It is very indicative that the prominent American politicians and experts give a high degree of significance for the Treaty: "Unilateral U.S. withdrawal from Open Skies would undermine American allies and friends" - that is the assessment of the situation with the OST by G. Shultz, W.J. Perry and S. Nunn in their memo sent to the US Administration and published in WSJ. ${ }^{33}$

From a political point of view, it is the OST, together with the Vienna Document 2011 on confidence and security-building measures that

${ }^{33}$ Open Skies Help keep the Peace with Russia by George P. Shultz, William J. Perry and Sam Nunn, WSJ oct.20 2019. [Electronic resource]. URL: https: // www. wsj. com 
represent a tool that, to some extent, ensures transparency and, accordingly, helps to stabilize the situation. We hope that common sense would prevail, and this important CBM will remain to be intact.

\section{Important addition}

On June 2, 2020, a very important and, in a sense, the unique document appeared in Russia. It can be described as a military-diplomatic memorandum in the field of nuclear deterrence. We are talking about the "Principles of the state policy of the Russian Federation in the field of nuclear deterrence". ${ }^{34}$

The document, among other things, is apparently directly related to the issues under discussion, since, for the first time in modern Russian history, it clearly formulates conditions and threats, in the presence of which Russia can and must use its nuclear missile potential.

These include the deployment of ballistic missiles, hypersonic weapons and the ABM systems by the countries that consider Russia as a possible adversary. In addition, the build-up by the likely adversary of generalpurpose forces on the borders of Russia and its allies, as well as the creation and deployment of missile defence assets and strike systems in space were identified as threats that could force Russia to use nuclear weapons in certain conditions.

These conditions for a nuclear strike by Russia are clearly formulated. This is the launch of ballistic missiles on the territory of Russia and its allies, a WMD attack against Russia, the impact on critical state or military facilities, as well as the aggression against Russia using conventional weapons with a threat to the existence of the Russian Federation as a state. In this context, the document is a follow-up of the existing military doctrine. ${ }^{35}$

\footnotetext{
${ }^{34}$ Указ Президента РФ от 02.06. 2020 № 355 « 0 основах государственной политики РФ в области ядерного сдерживания». - URL: https: //www.kremlin.ru Ukaz Prezidenta PF ot 02.06.2020 № 355 «Ob osnovah gosudarstvennoj politiki v oblasti jdernogo sderzhivanija». [Electronic resource]. - URL: https: //www.kremlin.ru

${ }^{35}$ Военная доктрина Российской Федерации (утв. Президентом РФ 25 декабря 2014 года. № Пр-2976). [Electronic resource]. - URL: https: //base.garant.ru/70830556/
} 
As paradoxical as it may sound, let us allow to assert that the document in terms of its essence, focus and clarity objectively works as a confidencebuilding measure, and not only among de jure and de facto nuclear states. It could as well be generally applied to the security issues in the EuroAtlantic area.

It distinctly recognizes that nuclear weapons are a last resort and are viewed solely as a deterrent. Besides, the conditions and procedures for making a decision on Russia's use of its nuclear potential are clearly formulated, and any country can correlate its military policy with the way how Russia will react to it.

At the same time, the document warns those who are deploying or preparing to deploy systems threatening the Russian nuclear deterrent forces on their territory that their actions will not be simply ignored.

Simultaneously, the document removes all speculations and concerns regarding Russia and its "aggressiveness" and debunks various nuclear strategies that were falsely attributed to Russia, such as, for example, "escalate to de-escalate" and others.

The reaction to this document of Russia's strategic opponents, the US, is very interesting. Thus, former US Deputy Secretary of State Frank A. Rose, well-known in the circles of arms control negotiators, and already cited in this thesis, asserts: "If Putin says that they will use nuclear weapons in exceptional circumstances, then it is much better than previous statements about the use of nuclear weapons against US allies because they participate in legitimate defense cooperation..."

\section{As conclusions}

It is becoming increasingly clear that the world is entering a phase of high international tension. The combination of the financial, economic, social, energy and oil crisis - and in various regions, the military and political crisis as well - with the coronavirus pandemic can lead to a sharp deterioration in relations between key world players. Contradictions are

[Voennaya doktrina Rossijskoj Federacii (utv.Prezidentom RF 25 dekabrya $2014 \mathrm{~g}$. № Pr-2976). - URL: https: //base.ga garant.ru/70830556/] 
growing. They are exacerbated by the contradictions between the globalistminded Western elites and those segments of them that are focused on national development.

Tensions are also growing in Europe. All this requires maximum mutual restraint and work to find adequate political and diplomatic steps aimed at strengthening confidence and strategic stability.

Obviously, the European direction remains central for Russian foreign policy, including because of the negative historical experience. It was Europe that posed the main threat to Russia's security and sometimes to its existence.

The current state of affairs in the field of European security is unlikely to satisfy all of us Europeans. It is necessary to develop new forms. A substantive and productive dialogue is required to overcome mutual fears and increase the level of trust. The re-establishment of professional contacts, including at the military level, is needed in order to avoid misunderstanding of each other's intentions and prevent the descent into an uncontrolled escalation of tension. As an urgent measure, it would be important to ensure the reduction of military activity along the Russia-NATO line of contact.

A reliable and long-term solution to the problems is possible in the modern world only on the sound basis of international law through cooperation between countries and their consolidation in the interests of solving common problems.

\section{References}

Castells M. The rise of the network society: The information age: economy, society, and culture. - John Wiley \& Sons, 2011. - T.1.

Clinton Rich. Strategic Report // RAND, Cal., 2017.

Daniel R Coats Director of National Intelligence/ Worldwid Threat Assessment of the US Intelligence Community. Febr. 13, 2018. - P. 15. [Electronic resource]. - URL: https//www.aremed-services.senate.gov/ imo/media/doc/Coats_03-06-18.pdf

Directive of the United States Department of Defense on Space Policy №3100.10, October 18, 2012 Space Directive [Electronic source] // 
Defense Technical Information Centre [official website]. - URL: http://www.dtic.mil/whs/directives/corres/pdf/310010p. pdf)

Draft - Treaty on the Prevention of the Placement of Weapons in Outer Space, the Threat or Use of Force against Outer Space Objects [Electronic source] // United [Official website]. - URL: http://www.un. org/ru/document/ods.asp? $\mathrm{m}=\mathrm{CD} / 1985$

Frank A. Rose. Growing global Cooperation on Ballistic Missile Defense. Remarks as prepared for delivery in Berlin, Germany. September 10, 2012. [Electronic resource]. The U.S. Department of State website. - URL: http: // www. state.gov/t/avc/rlss/ 197547.htm

Frank A. Rose. Implementation of the European Phased Adaptive Approach.

Remarks at Polish National Defense University Warsaw, Poland. April 18, 2013. [Electronic resource]. The U.S. Department of State website. URL: http: // www. state.gov/t/avc/rls/2013/207679.htm

Gompert D., Binnendijk H. Power to Coerce // RAND Cal., 2016. P.5-10.

Huntington S.P. The Clash of Civilizations and the Remaking of the World Order. - New York, N.Y.: Simon and Shuster, 1996. - 367 P.

Koblentz G.D. Strategic Stability in the Second Nuclear Age / Council on Foreign Relations. Special Report № 71. November 2014

Measuring Geopolitical Risk Caldara, Dario and Matteo lacoviello [Electronic resource]. - URL: https //dol.org/10.17016/IDDP.2018.1222

National Defense Authorization Act for Fiscal Year 2019 / Congress. [Electronic resource]. - URL: http://www.congress.gov>115/crpt/ hrpt676/CRPT-115hrtp676.pdf

NATO missile defense. FAS Special Report 1. September, 2011. [Electronic resource]. - URL: https:// fas.org/pubs/_docs/2011\%20Missile\% 20 Defense\%20 Report.pdf.

Nye J.S. The future of power. - Public Affairs, 2011. - 320 P.; Modern Political Warfare. Current Practices and Possible Responses. RAND. Cal., 2018. P.8

Open Skies Help keep the Peace with Russia by George P. Shultz, William J. Perry and Sam Nunn, WSJ oct.20 2019. [Electronic resource]. - URL: https: // www. wsj. com

Operations and Missions past and present. [Electronic resource]. - URL: https: //www.nato.inthepshnatohqtopics_52060 
Overextending and Unbalancing Russia. RAND. 2019. Modern Political Warfare. Current Practices and Possible Responses. - Cal., RAND. 2018. - P.8

Phillips W.R. Civil-Military Cooperation: Vital to Peace implementation in Bosnia // NATO Review. 1998. Vol.48. №1. P.22-25

Public support for peace building. September 2017/ Sociology June -July 2017. [Electronic resource]. - URL: www.revalgeldesigns.co.uk

Remarks by President Trump at Signing Ceremony for s.1790, National Defense Authorization Act for Fiscal Year 2020 // The White House, December 20, 1919.

Russian Military Power. - Defense Intelligence Agency, 2017. P.1-VII, +86.

Th.Freat, L.Kulesa, D.Raynova. Russia and NATO: How to overcome deterrence instability? / Euro-ATLANTIC Security Report/European Leadership Network, 2018.April. - P.2

Speech by NATO SecretaryGeneral Anders Fogh Rasmussen at Carnegie Europe. A force for Freedom. September 16. 2014. [Electronic resource]. - URL: https: // www.nato.int/cps/en/natohq/opinions_113063.htm? selectedLocale $=\mathrm{en}$

The globalizing role of NATO has been confirmed by the Active Engagement. Modern Defense strategic concept adopted in November 2010. [Electronic resource]. - URL: //https://www. nato.int/cps/ru/natohq/ official_texts_68580.htm

The National Defense Strategy of the United States of America, 2018. [Electronic resource]. The Department of Defense official website. - URL: https://www.defense.gov/Portals/1/Documents/pubs/2018-NationalDefense-Strategy-Summery.pdf

Tomes R. Releaning Countersurgency Warfare / US Army War College, 2004.; Overextending and Unbalancing Russia. RAND. 2019.

Trump reauthorizes U.S. Space Command / Spaceflight Now. [Electronic resource]. - URL: http://www.Spaceflightnow.com

2011 National Security Space Strategy (NSSS) [Electronic source] // Defense Technical Information Centre [official website]. - URL:http://www.dtic. mil/dtic/tr/fulltext/u2/a536546.pdf 
Военная доктрина Российской Федерации (утв. Президентом РФ 25 декабря 2014 года. № Пр-2976). [Electronic resource]. - URL: https: //base.garant.ru/70830556/

[Voennaya doktrina Rossijskoj Federacii (utv.Prezidentom RF 25 dekabrya 2014 g. № Pr-2976). - URL: https: //base.ga garant.ru/70830556/]

Герасимов В.В. Роль и место контроля над вооружениями в системе обеспечения безопасности Российской Федерации. Московская Конференция по Европейской Безопасности // Под ред. А.И. Антонова 23-24 мая 2013 г. [Gerasimov V.V. Rol' I mesto kontrolja nad vooruzhenijami v sisteme obespechenija bezopasnosti RF / pod redakzii A.I. Antonova 23-24 maja 2013].

Russian Military Power. - Defense Intelligence Agency, 2017. P.1-VII, +86.

Данилевский Н.Я. Россия и Европа. М.: Академический Проект, 2015. $602 \mathrm{c}$.

[Danilevskij N.YA. Rossiya I Evropa. M.: Akademicheskij Proekt, 2015. - 602 s.]

Журкин В.В. Европейская армия: Поражения и победы. Общая политика безопасности Европейского Союза. М.: Международные отношения, 2012.

Jurkin V.V. Evropejskaja armija: Porazhenija I Pobedi. Obshsaja politika bezopasnisti Evropejskogo Sojuza. M.: Mejdunarodnije ontnoshenija, 2012.

Как Франция собирается милитаризировать свою космическую доктрину / Le Monde. [Electronic resource]. - URL: https://inosmi.ru/ politic/20190726/245529943.html

Kak Franzija sobiraetcja militarizirivat` svoju kosmicheskuju doctrinu

Le Monde. - URL: https://inosmi.ru/politic/20190726/245529943.html

Клаузевиц К. фон. О войне. Избранное. М.: АСТ. 2019. - 318 с.

[Klauzevic K. fon. 0 vojne. Izbrannoe. M.: AST. 2019. - 318 s.]

НАТО утвердила концепцию альянса по сдерживанию в космосе / TACC. [Electronic resource]. - URL: https://tass.ru/mezhdunarodnayapanorama/6600988 
NATO utverdila konzepziju alijansa po sderzhivaniju v kosmose/TASS. [Electronic resource]. URL: https://tass.ru/mezhdunarodnayapanorama/6600988

Подберёзкин А.И. Значение Локальных Человеческих Цивилизаций (ЛЧЦ) как субъектов формирования международной обстановки (MO) в мире // ЦВПИ. 13 февраля 2020 [Electronic resource]. - URL: www.eurasian-defence.ru

[Podberyozkin A.I. Znachenie LCHC kak subjektov formirovaniya MO v mire // CVPI. 13 fevralya 2020. - URL: www/.eurasian-defence.ru]

Попов И.М., Хамзатов М.М. Война будущего. Концептуальные основы и практические выводы. Очерки стратегической мысли. 3-е изд., испр.М.: Кучково поле, 2019. - 832 с.

[Popov I.M., Hamzatov M.M. Vojna budushego. Konceptual'nye osnovy I prakticheskie vyvody. Ocherki strategicheskoj mysli. 3-e izd., ispr. M.: Kuchkovo pole. 2019. - 832 s.]

Указ Президента РФ от 02.06. 2020 № 355 « 0 основах государственной политики РФ в области ядерного сдерживания». - URL: https: //www.kremlin.ru

Ukaz Prezidenta PF ot 02.06.2020 № 355 « Ob osnovah gosudarstvennoj politiki v oblasti jdernogo sderzhivanija». [Electronic resource]. - URL: https: //www.kremlin.ru

Штоль В.В. Россия и Запад: несостоявшийся альянс, или Противостояние как неизбежность. СПб. : Алетейя. 2019. - 434 с.

[Shtol ' V.V. Rossiya i Zapad nesostoyavshijsya al yans, ili Protivostoyanie kak neizbezhnost'. SPb.: Aletejya.2019. - 434 s.] 